\title{
3D Simulation of Vibrating Diamond Grinding
}

Anatoly Grabchenko ${ }^{1}$, Vladimir Fedorovich ${ }^{1}$, Ivan Pyzhov ${ }^{1}$, János Kundrák ${ }^{2}$

${ }^{1}$ National Technical University "Kharkov Polytechnic Institute", Frunze Srt.21, Kharkov, 61002 Ukraine

${ }^{2}$ University of Miskolc, Institute of Manufacturing Science, Miskolc, Egyetemváros H-3515, Hungary

grabchenko@kpi.kharkov.ua, fedorovich@kpi.kharkov.ua,diamet@inbox.ru,janos.kundrak@uni-miskolc.hu

Keywords: 3D simulation, finite element model, diamond grinding wheel, vibrating diamond-abrasive machining

A method of 3D simulation of vibrating diamond-abrasive machining based on a finite element model of the process is worked out. Calculation of the deflected mode of grinding area is the evidence that high-frequency vibration has a considerable effect on the amount of fractured material. Equivalent stress in the grinding zone increases up to 1.5-2.0 times. By means of FEM simulation of ultrasonically assisted grinding it is found that when grinding without imposing high frequency vibrations the maximum load is concentrated on a certain face of diamond grain. This can lead to the fracture of a grain in contact area with a bond and subsequent untimely shedding of the grain from the bond. However, uniform distribution of the stresses along the grain when imposing high-frequency vibrations improves retention of the grain in bond.

\section{References:}

[1] KUNDRÁK, J. (2011). Alternative machining procedures of hardened steels, Manufacturing Technology, ISSN 1213-2489, , Vol. 11, No 11, pp.32-39

[2] NOVAK, M., DOLEZAL, R. (2012). G-Ratio in hardened steel grinding with different coolants, Manufacturing Technology, ISSN 1213-2489, Vol. 12. No 13. pp.192-197

[3] KUMABE, D. (1985). Vibrating cutting, Translated from Japanese by S.L. Maslennikov, Edited by I.I. Portnov, V.V.Belov. - Moscow: Mechanical Engineering, 424 p.

[4] FEDOROVICH, V.A. (2002). Elaboration of scientific fundamentals and methods of practical realisation of adaptability control at diamond grinding of superfirm materials: Thesis, Dr. Techn. Sc.: 05.03.01. National technical university "Kharkiv Polytechnic Institute", 466 p.

[5] HUANG J.M., BLACK, J.T. (1996). An Evaluation of Chip Separation Criteria for the FEM Simulation of Machining, Journal of Manufacturing Science and Engineering: Trans. of ASME, Vol. 118, No 4. pp.545-554

[6] MARKOV A.I. (1968). Ultrasonically assisted cutting of hard-to-work materials. - Moscow: Mechanical Engineering, $365 \mathrm{p}$.

[7] FRYDRYŠEK K. (2009). Aplikace pravděpodobnostni metody SBRA ve vědecko-technicke praxi (Application of Probabilistic SBRA Method in the Scientific and Technical Practice), inaugural dissertation in the branch of Applied Mechanics, Department of Mechanics of Materials, FME VŠB-TU Ostrava, CZ, pp.144

[8] BIL H., TEKKAYA A.E., KILIÇ E.S. (2005). 2D Finite Element Modeling of Machining: A Comparison of Different Approaches with Experiments, VIII International Conference on Computational Plasticity, CIMNE, Available at http://congress.cimne.com/complas05/admin/files/filepaper/p176.pdf, Barcelona

[9] GALLI, O. (2004). Hochleistungs Bearbeitung von Holz und Holzersatzstoffen mit PKD-Werkzeugen, Industrial Diamond review, Vol. 38, No 1, pp.45-46, access mode to the article: http://www.idr-online.com/german/pages/archive/2004_1/12_art/Art12_01_04.htm

[10] KRYVORUCHKO, D.V., ZALOGA, V.A. (2012). Simulation of Cutting Processes by means of Finite-Element Method, Methodological bases: monograph, Edited by V.A. Zaloga, University book, 450 p.

[11] KRYVORUCHKO, D.V. (2010). Scientific fundamentals of simulation of cutting processes using numerical procedures, Thesis, Dr. Techn. Sc.: 05.03.01. National technical university "Kharkiv Polytechnic Institute", 453 p.

[12] PYZHOV, I.N. (2009). Scientific fundamentals of shaping of edge tools made of polycrystalline superhard materials, Thesis, Dr. Techn. Sc.: 05.03.01. National technical university "Kharkiv Polytechnic Institute", 457 p.

[13] MAMALIS A.G., GRABCHENKO A.I., FEDOROVICH V.A., KUNDRAK J. (2009). Methodology of 3D simulation of processes in technology of diamond-composite materials, Int. J. Adv. Manuf. Technol. Vol. 43, Iss. 1112 , pp. $1235-1250$ 
[14] KOZAKOVA N.V., FEDOROVICH V.A. (2006). Estimation of Influence of Dimension and Grain Concentration on their Integrity when Sintering Diamond Wheels on Metal Bonds, Intern. scient-techn. collected papers "Cutting and tool in technological systems", Kharkov, NTU "KhPI", 71 pp. 64-71.

[15] MAMALIS, A. G., GRABCHENKO A. I., FEDOROVICH V. A., KUNDRAK J. (2012). Simulation of effects of metal phase in a diamond grain and bonding type on temperature in diamond grinding, The International Journal of Advanced Manufacturing Technology, Vol. 58, Issue:1-4, pp.195-200 DOI: 10.1007/s00170-011-3382-7

[16] MAMALIS AG, KUNDRAK J, MARKOPOULOS A, et al. (2008). On the finite element modelling of high speed hard turning, International Journal of Advanced Manufacturing Technology, Volume: 38 Issue: 5-6 pp.441-446 DOI: $10.1007 / \mathrm{s} 00170-007-1114-9$

Copyright $($ 2014. Published by Manufacturing Technology. All rights reserved. 